\title{
INTERFEROMETER MICHELSON DAN CCD WEBCAM SEBAGAI PENENTU FREKUENSI GETAR OBJEK
}

\author{
Afdhal Muttaqin, Nadia Mayani \\ Jurusan Fisika FMIPA Universitas Andalas \\ Kampus Unand Limau Manis, Padang, 25163 \\ Email: allz@fmipa.unand.ac.id
}

\begin{abstract}
ABSTRAK
Telah dilakukan penelitian pengukuran getaran suatu obyek dengan menggunakan interferometer Michelson dan CCD webcam. Pola intereferensi dihasilkan dari perbedaan lintasan laser HeliumNeon dengan panjang gelombang $632,8 \mathrm{~nm}$ melewati obyek getar speaker piezo yang diletakkan pada cermin uji. Pemberian frekuensi getar dimulai $5 \mathrm{~Hz}-30 \mathrm{~Hz}$ dengan kelipatan $5 \mathrm{~Hz}$ serta frekuensi $1 \mathrm{KHz}-20 \mathrm{KHz}$ dengan kelipatan $1 \mathrm{KHz}$. CCD webcam dapat merekam berkas sinar laser dari cermin referensi dan cermin uji dengan kemampuan CCD webcam 30 frame perdetik. Perubahan intensitas laser yang menggambarkan frekuensi getar obyek dapat dilihat pada frekuensi di bawah frekuensi CCD webcam.
\end{abstract}

Kata kunci : frekuensi getar dan interferometer Michelson

\section{PENDAHULUAN}

Interferometer Michelson merupakan instrumen yang dapat menghasilkan pola fringe yang dihasilkan dari perbedaan lintasan cahaya yang diterima oleh layar (Beiser, 1992, Guather 1990, Laud dkk 1998). Interferometer ini terdiri dari beam spitter, dua buah cermin yakni cermin referensi dan cermin uji. Jika cermin uji interferometer Michelson dipasang obyek uji seperti speaker piezo yang digetarkan dengan pembangkit sinyal generator, sumber cahaya laser dan fotodetektor yang dihubungkan dengan osiloskop dapat mengukur frekuensi getar suatu obyek. Kelemahannya adalah perubahan puncak dan lembah gelombang di osiloskop yang menggambarkan frekuensi getar objek, sulit untuk di amati karena gelombang berubah-rubah dan bergerak pada osiloskop (Singh, 1996, Tischler, 1992, Wibowo, 2003, Widodo, 1995).

Seiring dengan kemajuan teknologi maka pengukuran getaran suatu obyek atau benda melalui peribahan intensitas mengalami perkembangan, di mana fotodetektor dapat diganti dengan menggunakan CCD webcam. CCD webcam dapat merekam perubahan intensitas laser dan perubahan intensitas laser mengandung parameter fisis seperi frekuensi getar obyek. Pengoperasian interferometer Michelson, CCD webcam dan laser Helium-Neon sangat mudah sehingga dengan memanfaatkan keuntungan-keuntungan ini maka frekuensi obyek dapat ditentukan melalui perubahan intensitas laser.

\section{METODE PENELITIAN}

Instrumen penelitian seperti interferometer Michelson, laser Helium-Neon, sinyal generator, dan CCD webcam di susun seperti Gambar 1 : 


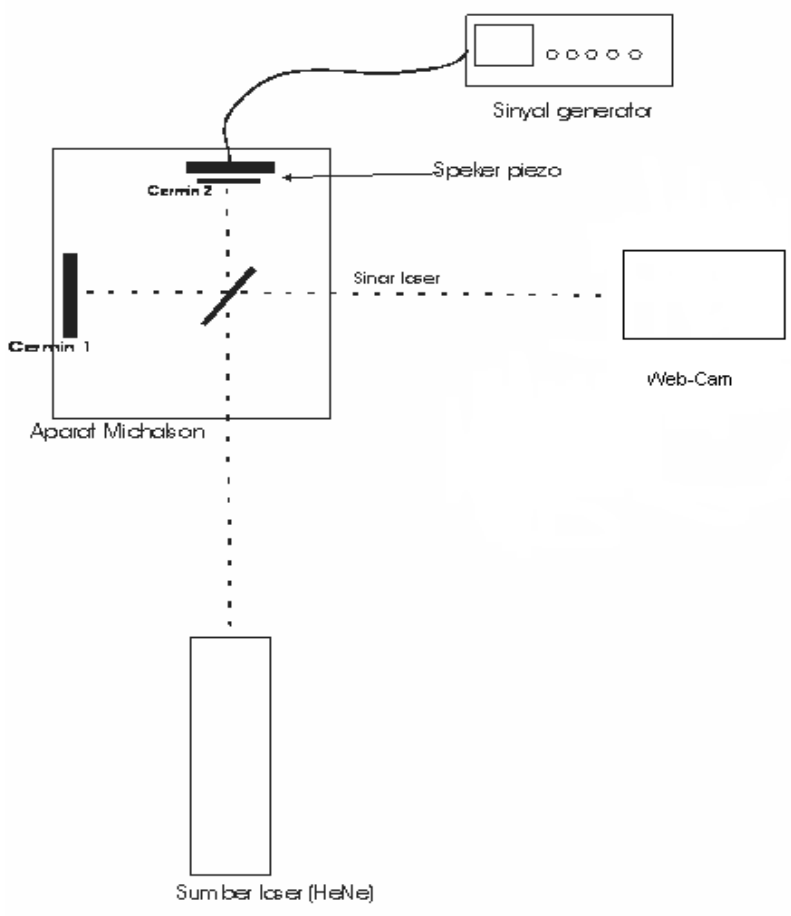

Gambar 1. Skema alat Interferometer Michelson untuk menentukan frekuensi getar objek

Sumber laser Helium-Neon ditembakkan ke beam splitter yang kemudian membagi berkas sinar laser menjadi dua bagian. Bagian pertama, berkas sinar laser diteruskan ke cermin referensi dan bagian ke dua berkas sinar laser diteruskan ke cermin uji yang telah diberi getaran dari sinyal generator. Berkas sinar laser dari cermin referensi dan cermin uji dipantulkan lagi ke beam splitter yang kemudian akan meneruskan ke dua berkas sinar ini ke CCD webcam. CCD webcam akan merekam pola interferensi yang dihasilkan dari perpaduan ke dua berkas sinar.Hasil rekaman CCD webcam berupa video klip avi dengan ukuran gambar 320 x 240 pixel dengan 30 frame perdetik. Video klip diolah dengan menggunakan matlab untuk mendapatkan data perubahan intensitas berupa angka. Pada matlab diambil satu piksel yang menggambarkan frekuensi getar yakni piksel yang dilewati intensitas cahaya maksimum berwarna putih dan intensitas minimum berwarna kehitaman. Bila tidak mengambil piksel tersebut maka perubahan intensitas tidak akan terbentuk.

Perubahan intensitas berupa angka yang diperoleh dari matlab dipindahkan ke microsoft office excel untuk menganalisa perubahan intensitas cahaya laser yang menggambarkan frekuensi getar pada tiap detik. Nilai intensitas yang ditampilkan adalah perbandingan antara nilai keluaran maksimum sebagai nilai intensitas awal (Io) yang dibandingkan terhadap intensitas yang diukur pada waktu yang diinginkan (It) dan dinyatakan dalam persen (\%) (Sutrisno, 1985, Halliday, 1984, Tjia, 1994) :

$$
I=\frac{I t}{I o} x 100 \%
$$




\section{HASIL DAN PEMBAHASAN}

\section{Perubahan Intensitas pada Frekuensi Getar yang Berbeda}

Setelah menjalani prosedur pengamatan maka perubahan intensitas cahaya yang direkam oleh CCD webcam, berupa video klip avi dengan ukuran gambar 320 x 240 piksel yang terdiri dari 30 frame per detik. Perubahan intensitas cahaya yang direkam oleh CCD webcam dapat dilihat pada gambar 2 dan 3 :

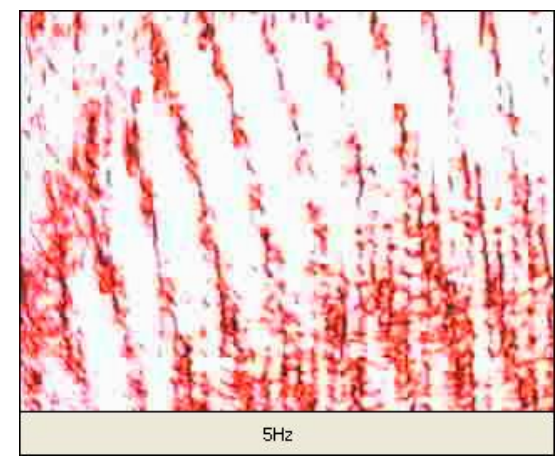

Gambar 2. Gambar klip video pada frekuensi $5 \mathrm{~Hz}$

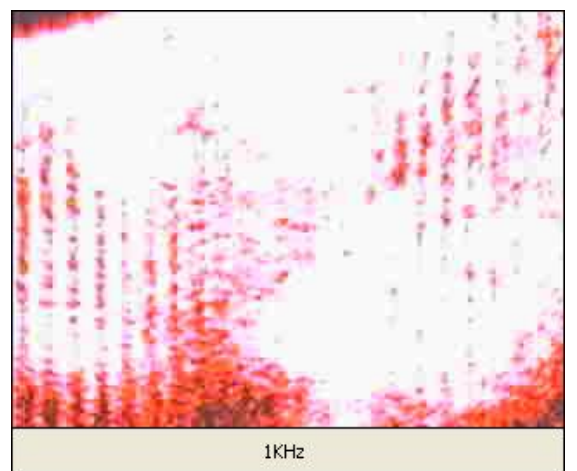

Gambar 3. Gambar klip video pada frekuensi $1 \mathrm{KHz}$

Kedua gambar di atas mewakili rentang pengukuran yang dilakukan, yaitu frekuensi $5 \mathrm{~Hz}$ sebagai frekuensi di bawah total frame CCD webcam perdetik, serta frekuensi $1 \mathrm{KHz}$ sebagai frekuensi di atas total frame CCD webcam perdetik. Dengan melihat tampilan awal menggunakan windows media player, perubahan intensitas dari frekuensi $5 \mathrm{~Hz}$ dapat dilihat secara langsung. Sedangkan pada frekuensi $1 \mathrm{KHz}$, perubahan intensitasnya tidak terlihat sebagaimana yang ditunjukkan oleh frekuensi $5 \mathrm{~Hz}$. Hal ini disebabkan oleh kemampuan CCD webcam yang mampu merekam 30 frame perdetik. Sehingga ketika terjadi perubahan pola di atas jumlah yamg mampu direkam oleh CCD webcam setiap detiknya maka CCD webcam akan gagal menangkap perubahan pola yang terjadi secara utuh.

\section{Frekuensi Getar Obyek pada Perubahan Intensitas}

Bila terdapat lima gelombang pada perubahan intensitas cahaya yang direkam CCD webcam selama satu detik berarti frekuensi getar obyek adalah $5 \mathrm{~Hz}$, sedangkan bila terdapat sepuluh gelombang berarti frekuensi getar obyek adalah $10 \mathrm{~Hz}$, sehingga frekuensi getar obyek dapat dilihat melalui perubahan intensitas cahaya laser melalui CCD webcam (pada gambar 11 dan gambar 15). CCD webcam memiliki kemampuan 30 frame perdetik, ini berarti CCD webcam dapat menangkap frekuensi getar lebih kurang 
$30 \mathrm{~Hz}$, frekuensi diatasnya tidak berfungsi dengan baik seperti frekuensi getar $1 \mathrm{KHz}-20$ $\mathrm{KHz}$.

Secara umum, pada frekuensi getar $5 \mathrm{~Hz}$ dan $1 \mathrm{KHz}$ CCD webcam mampu menangkap adanya perubahan pola intensitas yang terjadi. Perubahan pola intensitas sinar sebagai pola interferensi yang terdiri pita terang yang merupakan intensitas maksimum dan pita gelap yang merupakan intensitas minimum. Pita gelap ditunjukkan dengan warna kehitaman dan pita terang ditunjukkan dengan warna putih.

Di samping kemampuan CCD webcam, pemilihan piksel yang tepat pada matlab juga mempengaruhi grafik perubahan intensitas laser pada tiap detik yang menggambarkan frekuensi getar obyek. Gelombang yang menggambarkan frekuensi obyek melalui perubahan intensitas tidak akan terbentuk bila piksel tidak mengalami perubahan pita gelap dan pita terang meskipun pada frekuensi getar yang sama. Hal ini dapat dilihat pada gambar 4 sampai gambar 7 :

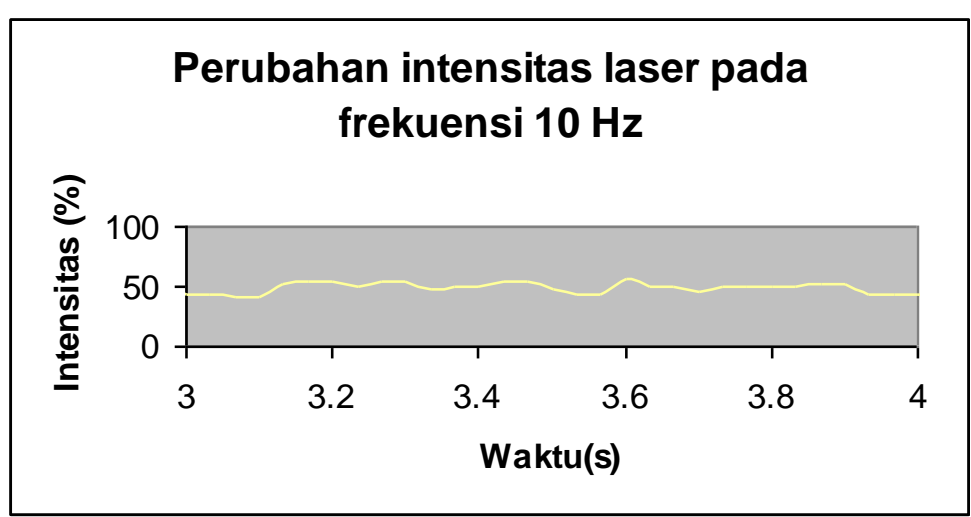

Gambar 4. Frekuensi getar obyek pada perubahan intensitas dengan frekuensi $10 \mathrm{~Hz}$ pada piksel $(96,11)$

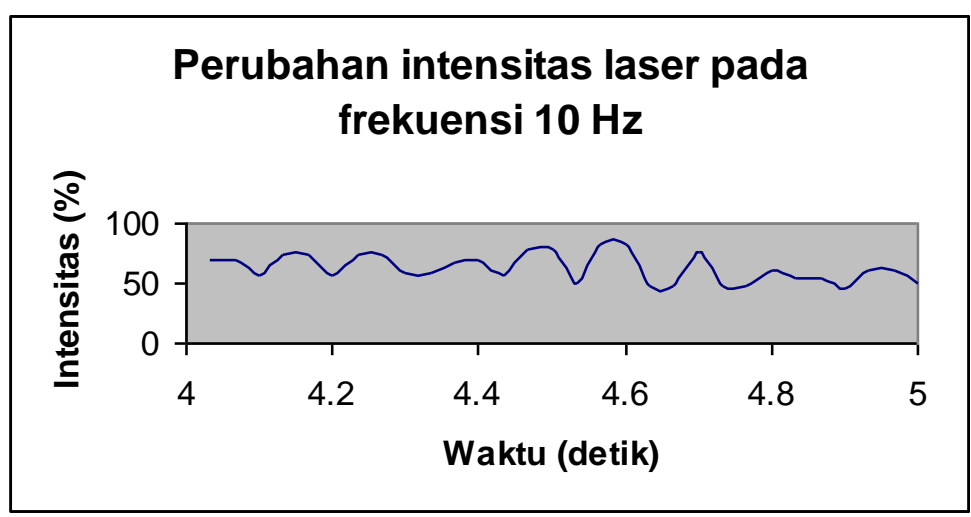

Gambar 5. Frekuensi getar obyek pada perubahan intensitas dengan frekuensi $10 \mathrm{~Hz}$ pada piksel $(96,11)$ 


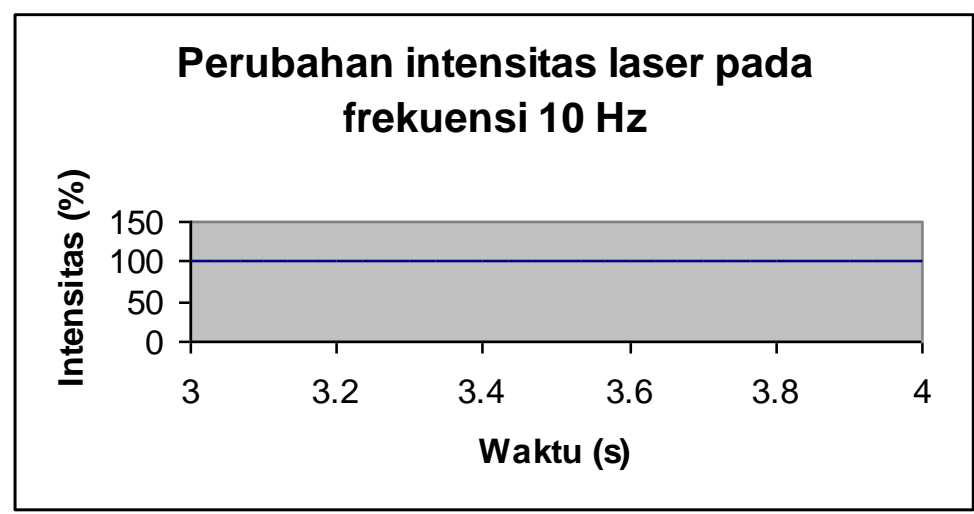

Gambar 6. Frekuensi getar obyek pada perubahan intensitas dengan frekuensi $10 \mathrm{~Hz}$ pada piksel $(50,50)$

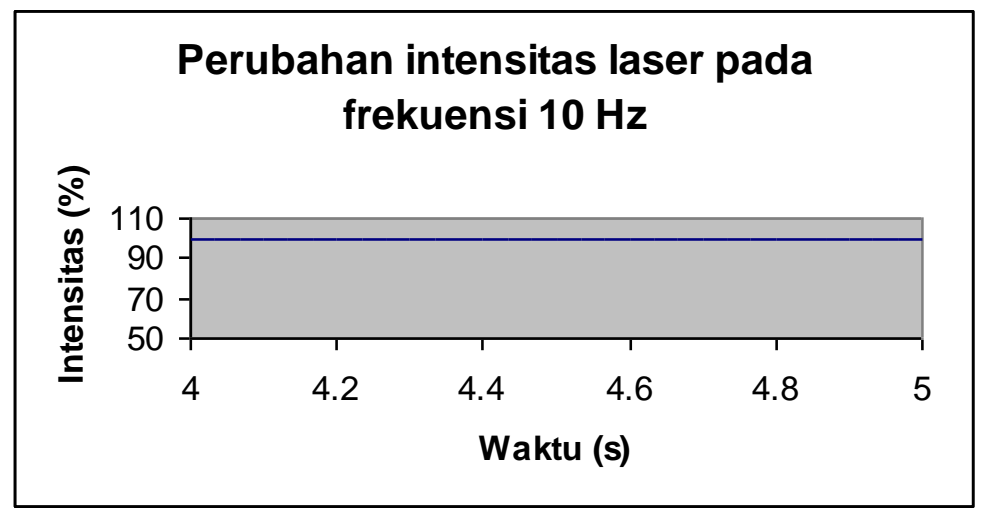

Gambar 7. Frekuensi getar obyek pada perubahan intensitas dengan frekuensi $10 \mathrm{~Hz}$ pada piksel $(50,50)$

Pada gambar 4 dan gambar 5 perubahan intensitas dengan frekuensi $10 \mathrm{~Hz}$ pada piksel $(96,11)$ diperoleh dari piksel yang mengalami perubahan pita terang dan pita gelap, sehingga nilai intensitasnya berubah-rubah dan bervariasi, sedangkan pada gambar 6 dan gambar 7 perubahan intensitas dengan frekuensi $10 \mathrm{~Hz}$ pada piksel $(50,50)$ tidak mengalami perubahan pita gelap melainkan pada piksel tersebut mengalami pita terang saja sehingga grafiknya berupa garis lurus dengan intensitas maksimum.

Dengan melihat pola terang sebagai intensitas maksimum, ternyata didapati bahwa kemampuan CCD webcam tidak dapat menangkap pola terang maksimum yang terjadi. Ini dapat dilihat dari pola intensitas yang terekam oleh CCD webcam. Pada pola tersebut terlihat bahwa terjadi pemotongan puncak (yang ditunjukkan dengan gambar panah pada gambar 8 dan gambar 9) akibat keterbatasan CCD webcam dalam merekam nilai intensitas di atas nilai yang dimaksud.

Keterbatasan CCD Webcam dalam menangkap perubahan pola terang maksimum disebabkan oleh kemampuan sensor cahaya yang di dalam CCD webcam masih belum begitu sensitif dengan perubahan cahaya yang terjadi. Hal ini dapat dilihat dari spesifikasi sensor cahayanya yakni ukuran sensor 4,86 x 3,64 mm², ukuran gambar 320 x 240 piksel. Semakin besar nilai piksel maka semakin sensitif perubahan yang ditangkap oleh suatu kamera. 


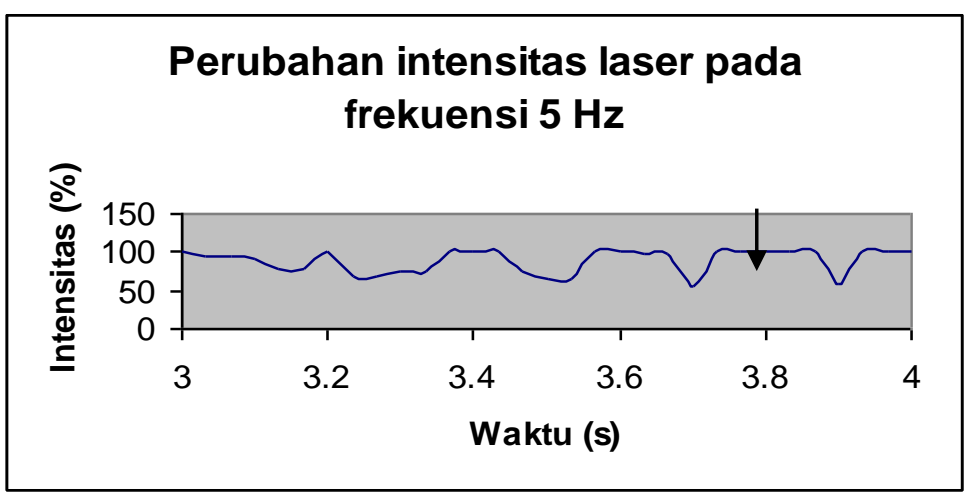

Gambar 8. Frekuensi getar obyek pada perubahan intensitas dengan frekuensi $5 \mathrm{~Hz}$

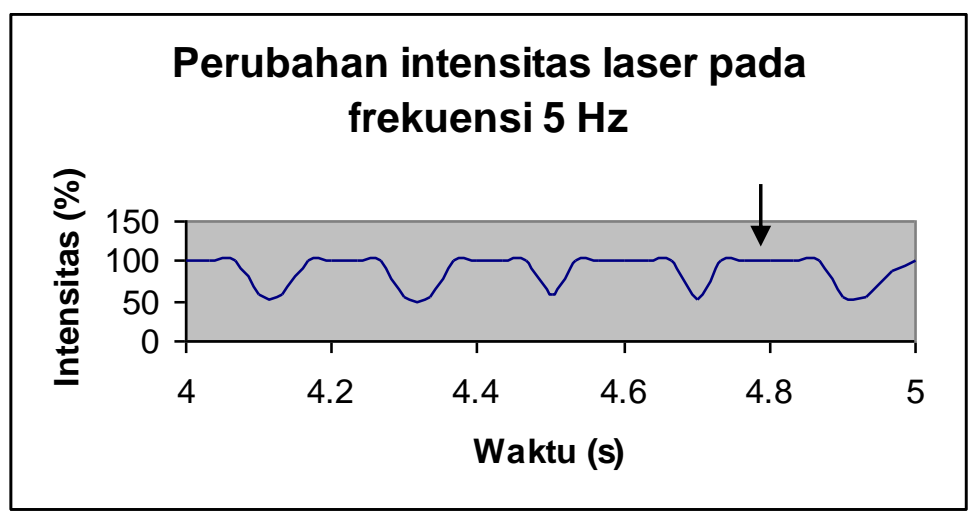

Gambar 9. Frekuensi getar obyek pada perubahan intensitas dengan frekuensi $5 \mathrm{~Hz}$

Di samping keterbatasan CCD webcam, keterbatasan alat seperti interferometer Michelson juga menjadi penyebab perubahan pola intensitas yang terjadi. Interferometer Michelson sering kali dikalibrasi karena setiap pergantian pengambilan data maka pola frinji akan berubah. Kondisi interferometer Michelson tidak stabil. Alat-alat yang digunakan hanya diletakkan pada meja biasa, sehingga getaran-getaran juga akan mempengaruhi data yang diambil.

Pada saat pengambilan data juga hendaknya memperhatikan kondisi pencahayaan ruangan. Ruangan untuk pengambilan data telah diusahakan gelap yakni dengan menutupi kaca jendela dengan karton hitam dan kain namun cahaya matahari juga masih masuk ke ruangan dan hal ini perlu disiasati caranya untuk penelitian selanjutnya.

Bila terdapat perubahan intensitas selama lima detik maka akan terlihat adanya peristiwa superposisi gelombang. Dua gelombang berkas sinar laser yang berasal dari cermin referensi dan cermin uji akan membentuk superposisi setelah melewati beam splitter. Superposisi inilah yang direkam oleh CCD webcam (pada gambar 10 dan gambar 11). Superposisi yang ditangkap oleh CCD webcam selama lima detik bervariasi pada frekuensi getar yang berbeda.

Perubahan intensitas pada frekuensi getar $1 \mathrm{KHz}$ sampai dengan $20 \mathrm{KHz}$ tidak akan menggambarkan frekuensi getar suatu obyek. Gambar 12 dan Gambar 13 merupakan perwakilan dari frekuensi di atas frekuensi kamera. 


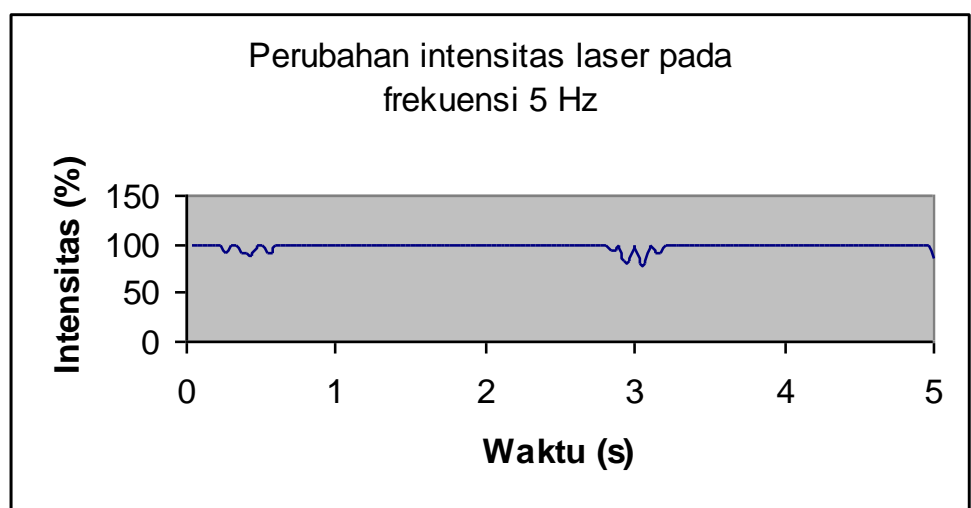

Gambar 10. Perubahan intensitas selama lima detik pada frekuensi $5 \mathrm{~Hz}$

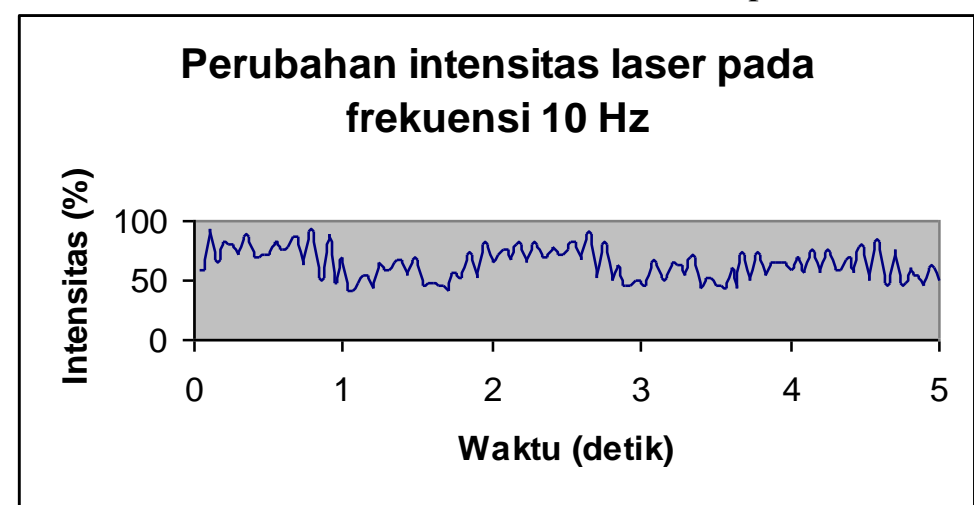

Gambar 11. Perubahan intensitas selama lima detik pada frekuensi $10 \mathrm{~Hz}$

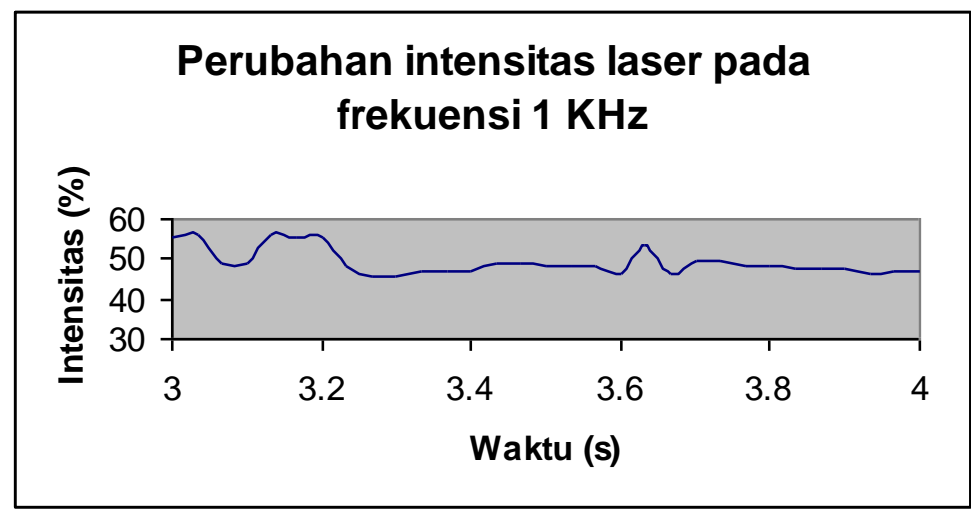

Gambar 12. Frekuensi getar obyek pada perubahan intensitas dengan frekuensi $1 \mathrm{KHz}$

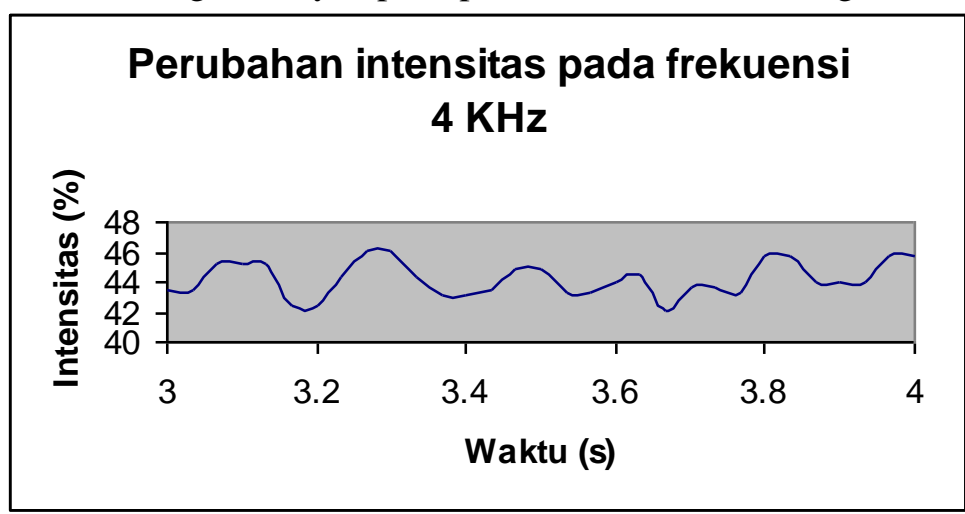

Gambar 13. Frekuensi getar obyek pada perubahan intensitas dengan frekuensi $4 \mathrm{KHz}$ 
Sebagaimana telah dijelaskan sebelumnya bahwa CCD webcam memiliki kemampuan 30 frame perdetik. Untuk frekuensi getar yang melebihi $30 \mathrm{~Hz}$ maka frekuensi getar tidak dapat dilihat pada perubahan intensitas. Untuk melihat frekuensi getar $1 \mathrm{KHz}$ ke atas diperlukan kemampuan CCD webcam dengan frame yang melebihi 30 frame perdetik. Bila dilihat posisi piksel frekuensi getar $1 \mathrm{KHz}$ ke atas (pada gambar 14 dan gambar 15) untuk penelitian kali ini akan mempengaruhi grafik perubahan intensitas terhadap waktu.

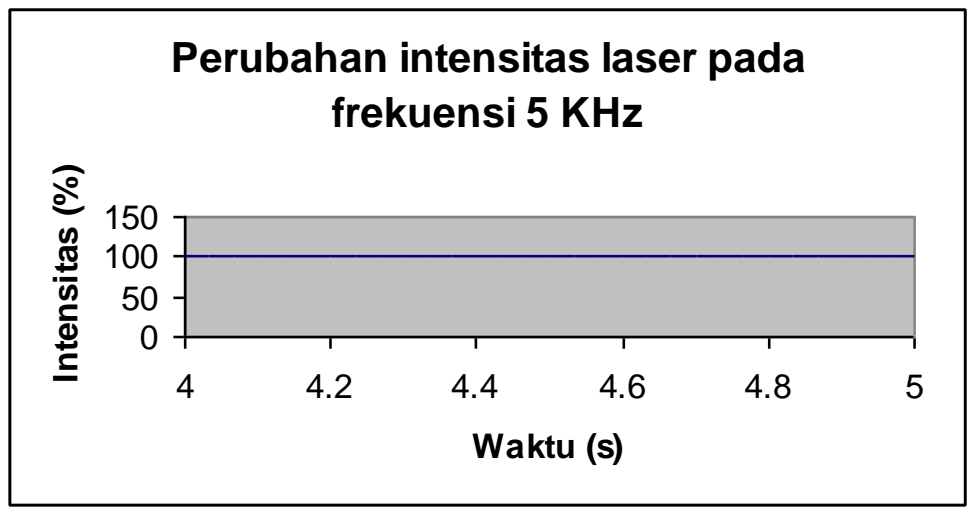

Gambar 14. Frekuensi getar obyek pada perubahan intensitas dengan fekuensi $5 \mathrm{KHz}$ pada titik $(50,50)$

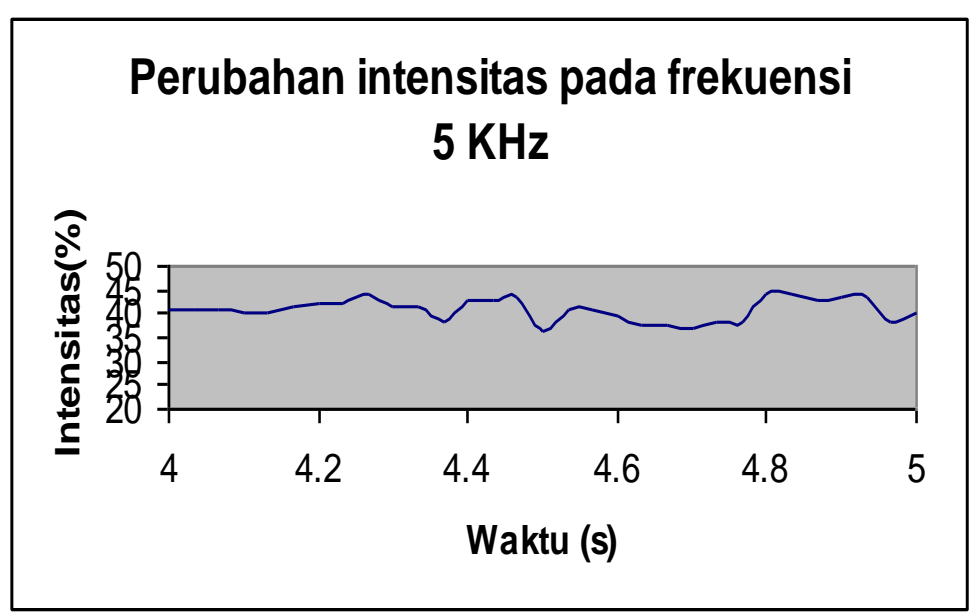

Gambar 15. Frekuensi getar obyek pada perubahan intensitas dengan fekuensi $5 \mathrm{KHz}$ pada titik $(200,100)$

Pada Gambar 14 pikselnya tidak mengalami pola perubahan pita gelap, hanya mengalami pita terang sehingga perubahan grafik hampir membentuk garis lurus dengan intensitas maksimum. Pada Gambar 15 piksel ini mengalami pola perubahan pita gelap dan pita terang sehingga grafiknya tidak berupa garis lurus. Frekuensi getar juga tidak akan tergambarkan pada frekuensi di atas frekuensi kamera. Hal ini juga disebabkan oleh keterbatasan CCD webcam yang tidak dapat menangkap pola terang maksimum yang terjadi.

Bila menggunakan kemampuan CCD webcam 30 frame perdetik, maka frekuensi getar obyek dapat dilihat dari perubahan intensitas untuk frekuensi getar tidak melebihi kemampuan kamera yakni frekuensi kurang lebih $30 \mathrm{~Hz}$. Untuk melihat frekuensi getar yang melebihi $30 \mathrm{~Hz}$ atau frekuensi yang lebih tinggi dibutuhkan kemampuan CCD webcam yang memiliki frame di atas 30 frame perdetik. 


\section{KESIMPULAN}

Penggunaan interferometer Michelson sangat bergantung pada sensor cahaya yang digunakan. Pada penggunaan CCD webcam dengan kemampuan 30 frame perdetik dapat digunakan untuk melihat interferensi akibat getaran dengan frekuensi getar di bawah 30 Hz. Kemampuan penangkapan interferensi sangat bergantung pada kemampuan CCD webcam sebagai sensor cahaya. CCD webcam tidak sensitif untuk perubahan cahaya dengan intensitas tinggi.

\section{TERIMAKASIH}

Peneliti mengucapkan terimakasih kepada Universitas Andalas yang telah membiayai penelitian ini melalui dana DIPA dengan nomor kontrak 158/H.16/PL/DIPA/2008

\section{DAFTAR PUSTAKA}

1. Beiser, A., 1992, Konsep Fisika Modern, Erlangga, Jakarta.

2. Guenther. R. D, 1990, Modern Optic, Jhon Wiley \& Sons, Duke University.

3. Halliday, 1984, Fisika, Erlangga, Jakarta.

4. Laud. B.B, Sutanto, 1988, Laser dan Optik Nonlinear, UI- Press.

5. Singh. Jasprit, 1996, Optoelectronics An Introduction to Material and Devices, The McGraw-Hill Companies,Inc.

6. Sutrisno, 1985, FISIKA DASAR Gelombang dan Optik, ITB, Bandung.

7. Tischler. Morris, 1992, Optoelectronics: Fiber Optics and Laser A Text- Lab Manual, Second Edition, Glencoe, Singapore.

8. Tjia, M.O., 1994, Gelombang, Dabara Publishers, Solo.

9. Wibowo. Priyo Budhi, 2003, Pengukuran Koefesien Muai Panjang dari Batang Aluminium dengan Menggunakan Metode Interferometer Michelson, Tugas Akhir S1, Jurusan Fisika, ITS, Surabaya.

10. Widodo, S., 1995, OPTOELEKTRONIKA Komunikasi Serat Optik, Andi Offset, Yogyakarta 